\title{
6- Yabancı/ikinci dil öğretiminde konuşma becerilerinin geliştirilmesine yönelik farklı bir uygulama alanı: Dublaj*
}

\section{Ezgi İNAL}

APA: İnal, E. (2021). Yabancı/ikinci dil öğretiminde konuşma becerilerinin geliştirilmesine yönelik farklı bir uygulama alanı: Dublaj. RumeliDE Dil ve Edebiyat Araştırmaları Dergisi, (Ö10), 118-126. DOI: $10.29000 /$ rumelide.1009044.

$\ddot{O} \mathbf{z}$

Yabancı/ikinci dil öğretimi çerçevesinde bireylerin temel iletişim becerilerini sosyal yaşamlarında kullanabilecekleri kazanımlar elde etmeleri gerekmektedir. Bireylerin sosyal aktörler olarak iletişim becerilerini kazanıp geliştirebilmelerinde konuşma becerisi odak noktayı oluşturmaktadır. Çünkü dil öğrenicileri konuşma becerilerinin gelişmesi ile birlikte sosyal yaşamda var olabilmekte ve kendilerini ifade edebilmektedirler. Nitekim bu da toplumsal uyumu sağlayıcı bir unsurdur. Dil öğretimi uygulamaları kapsamında konuşma becerilerine yönelik pek çok etkinlik tasarlanmakta ve uygulanmaktadır. Öğrenicilerin otantik öğrenme süreçlerini destekleyici ve genellikle görev temelli olarak yapılandırılmış bütün etkinlikler akıcı konuşma becerisinin sağlanabilmesini amaçlamaktadır. Dublaj uygulamaları da, daha önce çekimi tamamlanmış bir videonun (dizi, sinema, çeşitli dijital yapıtlar) kurgusal akışı içinde okuma ve sesletim unsurlarının bir arada bulunduğu, aynı zamanda da rol oynamayı gerektiren bir alan olarak ders içi yapılandırılmış etkinliklerde olduğu gibi yabancı/ikinci dil öğrenicilerinin çok yönlü gelişimleri için kullanılabilir. Ayrıca dublajda kurgu metninin doğru okumaya katkısı, söz konusu videoların görsel-işitsel dengeyi sağlaması, dikkat, odaklanma ve temelde metnin doğru seslendirilmesine yönelik sesletim yeterliklerinin güçlendirilebilmesi gibi özellikleri düşünüldüğünde bu alandaki uygulamaların yabancı/ikinci dil öğrenicileri için işlevsel olacağı düşünülmektedir. Bu çalışmada dublaj, dublajın özellikleri ve uygulamalarına yönelik literatür taraması yapılmış, araştırmacılara söz konusu uygulamaların hem yüz yüze hem de uzaktan yabancı/ikinci dil öğretiminde nasıl kullanılacağına dair önerilerde bulunulmuştur.

Anahtar kelimeler: Yabancı dil, ikinci dil, konuşma becerisi, dublaj

\section{A different field of application to develop speaking skills in foreign/second language teaching: Dubbing}

\begin{abstract}
Within the framework of foreign/second language teaching, individuals need to acquire some gains to use their basic communication skills in their social lives. Speaking skill is the focal point for individuals to gain and develop their communication skills as social actors because language learners can exist in social life and express themselves by developing their speaking skills. As a matter of fact, this is a factor that ensures social cohesion. Many activities are designed and implemented for speaking skills within the scope of language teaching practices. All activities that are generally task-
\end{abstract}

Dublaj sanatıyla tanışabilmem ve bu alanda çalışmalar yapabilmemde büyük emekleri olan Sestanbul Sanat Akademisi kurucusu ve dublaj sanatçısı Sayın Cemal Erdoğan’a sonsuz teşekkürlerimle.

Öğr. Gör., İstanbul Aydın Üniversitesi, Eğitim Fakültesi, TÖMER (İstanbul, Türkiye), ezgiinal1@aydin.edu.tr, ORCID ID: oooo-0002-1573-9401 [Araştırma makalesi, Makale kayit tarihi: 19.09.2021-kabul tarihi: 20.10.2021; DOI: 10.29000/rumelide.1009044]

RumeliDE Dil ve Edebiyat Araştırmaları Dergisi Osmanağa Mahallesi, Mürver Çiçeği Sokak, No:14/8 Kadıköy - ISTANBUL / TÜRKIYE 34714 e-posta: editor@rumelide.com tel: +90 $5057958124,+902167730616$
Address

RumeliDE Journal of Language and Literature Studies

Osmanağa Mahallesi, Mürver Çiçeği Sokak, No:14/8

Kadıköy - ISTANBUL / TURKEY 34714

e-mail: editor@rumelide.com,

phone: +90 505 7958124, +90 2167730616 
based and support learners' authentic learning processes aim to provide fluency in speaking skills. Dubbing practices are also used for foreign/second language learners as in classroom structured activities as an area where reading and pronounciation elements coexist within the fictional flow of a previously recorded video (series, movies, various digital works) and can be used for their versatile development as well as it requires role-playing. In addition, considering the contribution of the fiction text to correct reading in dubbing, the audio-visual balance of the videos in question, the ability to strengthen the pronunciation competences for attention, focus and the correct pronunciation of the text, it is thought that the applications in this field will be functional for foreign/ second language learners. In this study, a literature review was conducted on dubbing, the features and applications of dubbing, and suggestions were made to researchers on how to use these applications in both faceto-face and distance foreign/second language teaching.

Keywords: Foreign language, second language, speaking skill, dubbing

\section{Giriş}

Yabancı/ikinci dil öğretimi son yıllarda iletişim odaklı çalışmalarla ön plana çımaktadır. Dil öğretiminin yalnızca belirli dil bilgisi kurallarını öğrenmek ve bunu uygulamaya çalışmak olmadığı bunun yanı sıra dil öğrenen bireyin bir sosyal aktör olarak toplumsal yaşamda yer alabilmesini sağlayıcı unsurlar bütününden oluştuğu ifade edilmektedir (CEFR, 2020). Bu nedenle dil becerilerinin aktif ve bağlama uygun kullanılabilmesi önem arz etmektedir. Akpınar ve Aydın (2009) çok duyulu öğretme stratejilerinin ve ortamların hazırlanmasının yabancı dil öğretimine katkılar sağlayabilecek potansiyele sahip olduğunu vurgularlar. Dolayısıyla çok duyulu bir eğitim dil becerilerinin çok yönlü kazandırılabildiği süreçleri içermesi bakımından oldukça önemlidir.

Dil becerileri içinde özellikle konuşma becerisi günlük iletişimin sağlanabilmesi ve bireylerin toplumsal hayatın bir parçası olabilmeleri; toplumsal uyumun bir parçası olması bakımından önemlidir. Buradan hareketle dil öğrencilerine yönelik olarak konuşma becerisinin edimsel süreçlerle desteklendiği uygulamalar hem yüz yüze hem de uzaktan yabancı/ikinci dil öğretiminin bir gereği haline gelmiştir.

$\mathrm{Bu}$ çalışmada, yabancı/ikinci dil öğrenenlerin dublaj çalışmaları ile konuşma becerilerine nasıl katkı sağlanabileceği sorusuna yanıt aranmıştır.

\section{Yöntem}

Çalışma, konuyla ilgili alanyazının taranmasıyla hazırlanmış bir derleme makalesidir. Derleme çalışmaları bir konuyu bir araştırma problemine yanıt aramaktan farklı olarak ilgili konuyu alanyazın kapsamında inceler ve bu makalelerde konu hakkında gerçekleştirilmiş birden fazla araştırma bulgusuyla eleştirel bir analiz yapılır. (Karaçam, 2013). Bu çalışmada dublaj, dublajın özellikleri ve uygulamalarına yönelik literatür taraması yapılmış, araştırmacılara söz konusu uygulamaların hem yüz yüze hem de uzaktan yabancı/ikinci dil öğretiminde nasıl kullanılacağına dair önerilerde bulunulmuştur.

\section{Konuşma becerisi ve özellikleri}

Konuşma, insanlar arasındaki iletişimi sağlayan önemli bir beceridir. Konuşma becerisinin ikinci/yabancı dil öğrenme ortamlarında geliştirilebilmesi dil öğrenicilerinin hedef dili öğrenme ve kültüre adapte olma sürecine katkıda bulunmaktadır. $\mathrm{Bu}$ çerçevede konuşma becerisinin temel

\footnotetext{
Adres Address

RumeliDE Dil ve Edebiyat Araştırmaları Dergisi $\quad$ RumeliDE Journal of Language and Literature Studies

Osmanağa Mahallesi, Mürver Çiçeği Sokak, No:14/8 Osmanağa Mahallesi, Mürver Çiçeği Sokak, No:14/8

Kadıköy - ÍSTANBUL / TÜRKIYE 34714 Kadıköy - ISTANBUL / TURKEY 34714

e-posta: editor@rumelide.com e-mail: editor@rumelide.com,

tel: +90 505 7958124, +90 2167730616 phone: +90 505 7958124, +90 2167730616
} 
niteliklerinden söz etmek gerekir. Bu niteliklerin tam ve uyumlu olmasıyla doğru bir konuşmanın gerçekleştirilmesi mümkündür. Taşer (2012) bu nitelikleri sesin varlığını ifade eden konuşmanın fiziksel niteliği, sesin çıkışını ve fizyolojik ses araçlarını kapsayan konuşmanın fizyolojik niteliği, anlam ve anlama bağlı süreçleri içeren konuşmanın psikolojik niteliği ile toplumun iletişimsel alışverişini içeren konuşmanın toplumsal niteliği olarak dört başlıkta ele almıştır. İyi bir konuşmacının konuşmaya bütünüyle hâkim olması ve bu dört niteliğinin birbiriyle uygun olması beklenir. Bu niteliklerin uyumu fizyolojik nedenlere bağlı olabildiği gibi psikolojik ve sosyolojik nedenleri de olabilir. Bu nedenle dil öğrenirken konuşma becerisine yönelik motivasyon önemli bir gerekliliktir (Jabbarova, 2020). Bir başka ifade ile konuşma motivasyonu yüksek öğrencilerin yabancl/ikinci dil öğrenme süreçlerinin istendik düzeyde gerçekleşmesi mümkün olabilir.

Konuşma becerisi dil becerileri içinde en yüksek öneme sahiptir (İşisağ ve Demirel, 2010; Al-Sobhi ve Preece, 2018; Rao, 2019) nitekim bu beceri, iletişimin tarzını belirler ve ilişkileri şekillendirir. Dahası, Hussain konuşma becerisinin yabancı/ikinci dil öğretimindeki kritik bir yere sahip olmasından hareketle yabancı/ikinci dil müfredatının konuşma becerisi ve telaffuza odaklanması gerektiğini savunur. Bu bağlamda en genel kapsamda konuşma becerisi üç bilgi alanını içermektedir (Hamidova ve Ganiyeva, 2020, s. 19):

- Doğru kelimeleri doğru telaffuz ile doğru sırada kullanmak,

- Mesajın olması gerektiği gibi anlaşılması,

- Kim kiminle hangi koşullarda ne hakkında ve hangi nedenle konuştuğunu anlamak.

Dolayısıyla CEFR'de (2020) da vurgulandığı gibi iletişim sürecini destekleyici etkinliklerle konuşma becerisinin kazandırılması oldukça önemlidir. Çünkü gerçekleştirilecek uygulamalar kapsamında öğrencilerin günlük senaryoları tanımaları ve bu sayede konuşma becerilerini geliştirebilmeleri oldukça önemlidir (Hamidova ve Ganiyeva, 2020, s. 21).

\section{Tablo 1}

CEFR Kazanımlarında Konuşma Becerisine Yönelik Genel Çerçeve

\begin{tabular}{ll}
\hline Düzey & Genel Çerçeve \\
\hline A1 Düzeyi & Basit ve kalıplaşmış cümleler kullanır. Kendini ve çevresini tanıtır. \\
A2 Düzeyi & Gündelik yaşam hakkında ve uygun cümleler kurabilir. Betimlemeler yapar. \\
B1 Düzeyi & İlgi alanlarıyla ilgili ve benzer bağlamda cümleler kurabilir. \\
B2 Düzeyi & Bir konu hakkında ayrıntılı betimlemeler yapar ve akıcı cümleler kurabilir. \\
C1 Düzeyi & Farklı alanlardaki konuları anlamlandırabilir ve herhangi bir konuyu alt başlıklarıyla \\
& beraber açıklayabilir, sunabilir. \\
C2 Düzeyi & İyi seviyede bir telaffuzla düşüncelerini akıcı, mantıksal çerçevede ve anlaşllır aktarabilir. \\
\hline
\end{tabular}

(CEFR, 2020)

Nitekim Tablo 1'de görülen iletişim odaklı kazanımlarla gerçekleşecek uygulamalar ve bu kapsamda da oyunlar, yabancı/ikinci dil öğretiminde olumlu etkiye sahiptir (Dewi, Kultsum ve Armadi, 2017). Bunun yanında öğrencilerin konuşma becerilerinin gelişiminde dijital hikâye anlatımının (James, Yong ve Yunus, 2019; Eissa, 2019) ve ezber çalışmalarının (Al-Sharabi, 2020) da olumlu katkısı olduğu ifade edilmektedir.

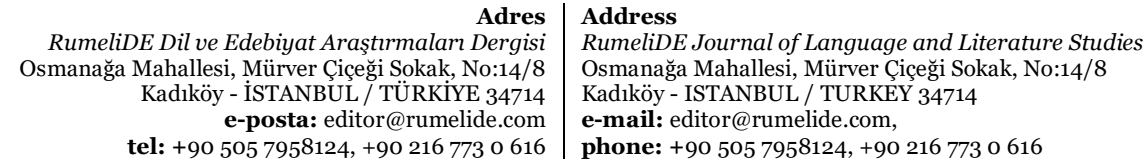

RumeliDE Dil ve Edebiyat Araştırmaları Dergis Kadiköy - ISTANBUL/TÜRKIYE 34714 tel: +90 $5057958124,+902167730616$ 
Konuşma becerilerini geliştirebilmek küresel şartlarda kendine bir yer bulabilmenin ve çeşitli iş̧ imkânları sağlayarak sosyalleşmenin en önemli yoludur. Bu nedenle öğretmenler de bu beceri için özel çaba sarf etmelidir (Rao, 2019, s. 10-11). Literatürde öğreticilerin konuşma becerilerine yönelik yeterlikleri vurgulanmaktadır (İnal, 2020). Hussain (2017) çalışmasında öğreticilerin sınıftaki olası aksaklıkları ve hataları profesyonel bir şekilde karşılamanın gerekliliği ile öğreticilerin konuşma becerisi kapsamında öğreticilerin kendi telaffuzlarının da doğru olması gerektiğinin altını çizer.

Rao (2019, s. 11) üç çeşit konuşma durumundan söz eder ve her konuşma durumunun kendine özgü bazı aşamaları bulunmaktadır:

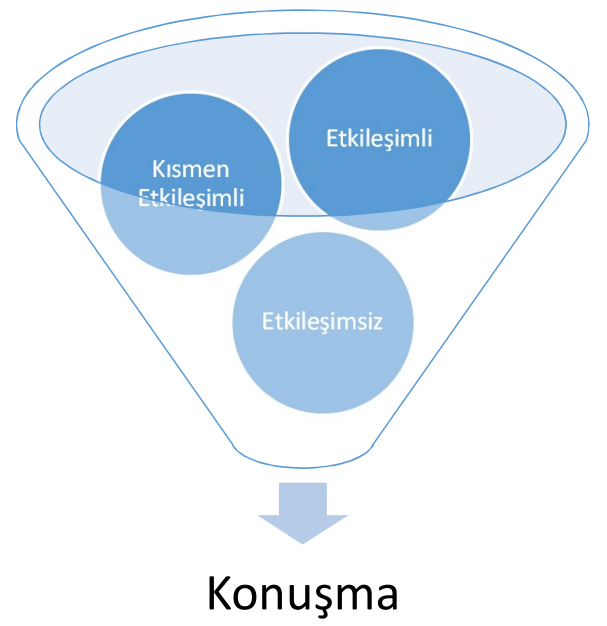

Şekil 1. Konuşma durumları (Rao, 2019)

Günlük yaşamda farklı konuşma durumlarında yer alabilen birey, resmi ve resmi olmayan ortamlarda çeşitli konuşma girdilerine maruz kalır. Bu bakımdan özellikle bugün görsel işitsel araçların ve dijitalleşmenin yabancı/ikinci dil öğrenicilerine özgür öğrenme ortamları sunduğu görülmektedir. Bu bakımdan Arslan (2017, s. 43) da formal ortamlar kadar informal öğrenme ortamlarında dil ediniminin öneminden söz ettiği çalışmasında görsel-işitsel araçların ve teknoloji odaklı eğitimin kolaylaştırıcı olduğunu vurgular. Ayrıca konuşma becerilerinde medya araçlarının kullanıldığı ve faydalı olduğu bilinmektedir (Meinawati vd., 2020). Görsel-işitsel unsurların yabancı/ikinci dil öğretimindeki öneminden hareketle kullanılacak bütün teknik uygulamalar öğrenciler için hem farklı hem de yeni dil öğrenme deneyimleri kazanmalarına yardımcı olması bakımından değerlidir.

\section{Konuşma becerisi ve dublaj}

Dublaj, rol oynama, okuma, dinleme, yazma, konuşma, dikkat, telaffuz gibi unsurları barındıran, görselişitsel teknolojilerin gelişimi ile son yllarda daha hızlı tüketilen (Perego ve Pacinotti, 2020, s. 41) ve dil öğretim süreçlerinde otantik bir öğrenme ortamı sunmaya katkı sağlayacak 199o'dan itibaren varlığını daha profesyonel hissettiren özel bir alandır. Dublaj, maliyetli ancak hedefe ulaşmada gerçekçi ve üretmeye uygundur. Ayrıca doğru teknik, inandırıcılık, fonetik senkronizasyon(eşleme), kinestetik eş zamanlılık, aşırılıklardan uzak durma, seste sorunsuzluk gibi unsurları içinde barındırmakta (Chaume, 2020, s. 111) bu yönüyle çok yönlülüğü sağlamaktadır. Genel değerlendirmelere uygun olarak Göçmen’in (2018) çalışmasında dublaj çalışması okuma becerisine yönelik otantik doküman olarak sınıflandırılmıştır. Ancak bilinmektedir ki dublaj okuma, dinleme, not alma süreçleriyle de yazma

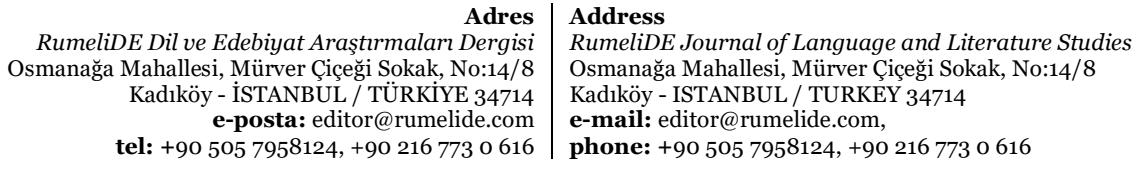


becerisinin geliştirilmesine yönelik işlevsel bir alandır. Bu bağlamda dublajla gerçekleştirilecek çalışmalara yönelik uygulamalarda öğrencilerin ders içinde uygulayabilecekleri filmlere yönelik görselişitsel çeviriden de söz etmek gerekir (Pérez González, 2009):

- Altyazı ile sunum

- Sözlü aktarım ile sunum (Dublaj, sesli betimleme)

Bu uygulamalarda yer alan görsel-işitsel çeviride altyazı uygulamaları daha çok okuma becerisiyle ilgili olduğundan konuşma becerisiyle doğrudan ilgili olan kısım sözlü aktarım ile ilgili alt başlıktır. Bu sözlü aktarım çalışmalarında öğrenciler orijinal filmlere kendileri dublaj yapabilecekleri gibi, hâlihazırda hedef dilde dublaj yapılmış filmlere de yeni metinler oluşturarak yeni ürünler ortaya koyabilirler.

Görsel-işitsel söylem standart bir çeşitliliğe sahip olması ve herkesçe anlaşılabilir, mümkün olduğunca sade ve günlük dil özelliklerine sahip olduğundan dil öğrenicilerinin yabancı/ikinci dil öğrenme süreçlerinde metni daha kolay anlamlandırmalarına yardımcıdır (Koç, 2020, s. 765). Bu bakımdan alanyazın incelendiğinde diziler ve filmlerin dil öğretiminde sıklıkla kullanılan ders materyalleri olduğu görülmektedir. Ülker ve Sütçü (2019) diziler ve filmlerde yer alan altyazılarla ilgili çalışmalarında dizi ve filmlerin yabancı dil öğreniminde faydalı olduğu sonucuna varmışlardır. İşcan (2011) çalışmasında filmlerle yapılan çalışmaların hem kültürel yansıtıcı hem de dil öğrenme motivasyonunu artırıcı olarak ifade eder. Benzer şekilde Kardaş (2017, s. 269-270) da çalışmasında hedef kültürle en kısa yoldan tanışma yolunun filmler olduğunu ve özellikle uzun metrajlı filmlerin orta seviye (B1-B2) ve sonrasında kullanılmasının daha uygun olduğundan söz eder. Bir başka çalışmada ise Ünlüer Arabacı (2015) hem kısa metrajlı hem de uzun metrajlı filmlerin dil öğretiminde faydalı olduğunu belirtmektedir. Yine İşcan ve Karagöz (2016), işitsel ve görsel araçların dil öğretiminde kullanılmasının faydalı olduğu ve günümüzde dil öğretiminde kullanılan işitsel ve görsel araçların başında video ve filmlerin geldiğini vurgulamaktadırlar. Ülker (2020), çalışmasında dizilerin yabancı dil öğretiminde kullanılabilir olduğunu, öğrenciler tarafından da informal öğrenme ortamlarında sıklıkla tercih edildiğini belirtmektedir.

Zeytinkaya (2018) derslerde kullanılan film odaklı etkinlikler arasında dublajın da son dönemde teknolojik gelişmelere bağlı olarak rahatlıkla kullanılabileceğini bu çerçevede yapılandırılmış derslerin pasif ders süreçlerinden kurtarılarak ilgi çekici olacağını vurgulamaktadır. Bu bakımdan reklam, dizi ve filmlerde kullanılan dublaj etkinlikleri doğru yapılandırıldıkları takdirde ders içeriğini zenginleştirici özelliklere sahip olabilir.

Dublaj, bazı kültürel kodlara uyum sağlamayı gerektirir. Bu da yabancı/ikinci dil öğrenicilerine yaşayarak öğrenmenin rol ile bir simülasyonunu(benzetimini) sağlar. Böylece uygulamalar esnasındaki slk tekrarlar, rol yapma (Ünsal, 2019; Kesici, 2021) ve diyaloglar dil öğrenimine yönelik eksikliklerin giderilmesinde önem arz etmektedir. Dublaj çalışmalarında söyleyiş, vurgu, kültürel referanslar ve söz konusu dil edimleri öğrencilerin dil deneyimleri bakımından hem eğlenceli hem de özel bir yol olarak karşımıza çıkmaktadır. Bu kapsamda Chaume (2020), dublajın dil edinimine katkıları olduğunu ifade eder. Bu durum, hem dublajın iç dinamiğini sağlayan ses ve buna bağlı olarak konuşma ile dinleme; ayrıca dış dinamiğinde yer alan okuma ve not alma bağlamında okuma yazma becerilerini kapsayıcı bir hal almaktadır. Dil öğretimi çerçevesinde dublajla beraber kullanılan temel unsurları şöyle sıralamak mümkündür:

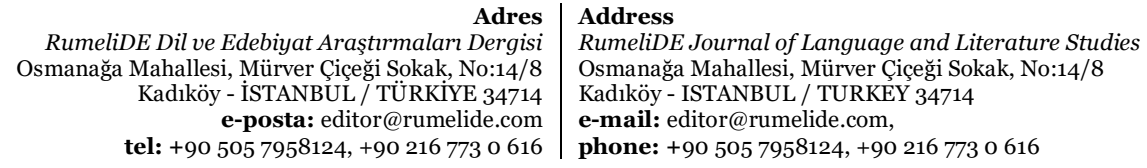



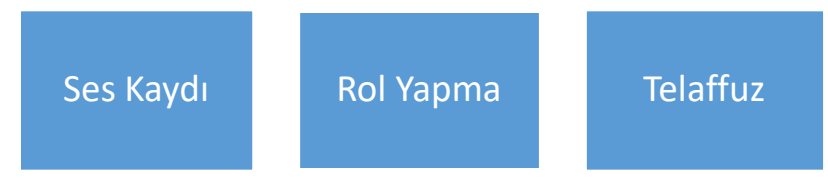

Şekil 2. Dublajın dil öğretimini destekleyici temel unsurlar

Ses kaydr: Diyora ve Diloza (2020) filmlerin konuşma becerisini geliştirmede faydalı olduğunu savundukları çalışmada ve konuşma pratiğini kaydetmenin dikkat edilmesi gereken yerler konusunda öğretici olduğundan da söz eder. Bu bağlamda dublaj yönetmeni görevindeki öğretmen, gerekli noktalarda müdahale ederek ve yapılan kayıtları öğrencilerle anlık paylaşarak telaffuz hataları ya da edimsel süreçler hakkında rahatlıkla geribildirimde bulunabilir.

Rol Yapma: Alanyazında dramatizasyon çerçevesinde konuşma becerisinin geliştiği vurgulanmaktadır (Sirisrimangkorn, 2018; Aykaç ve Çetinkaya, 2019; Rao, 2019; Göktürk, 2019; Çelik, 2019; Göktürk, Çalışkan ve Öztürk, 2020; Çilek, 2021). Dublaj da mikrofon oyunculuğu olduğundan rol yapma dublajın odağında yer almaktadır.

Doğru Telaffuz: Dublajda telaffuz da oldukça önemlidir (Chaume, 2020). Dublaj yapılması planlanan telaffuz çalışmalarını ilgi çekici hale getirmeye yardımcı bir olabilir. Çünkü dublaj, hangi dilde gerçekleşiyorsa o dilin ve dilin ait olduğu kültür dairesinin karakteristik özelliklerini içerir.

Şenyiğit ve Okur (2019), konuşma çalışmalarında telaffuz uygulamalarının planlı bir şekilde gerçekleştirilmesi gerektiğini savunurlar. Bu kapsamda gölgeleme (doğru bir konuşmayı tekrarlama), sesli okuma, bilgisayar tabanlı uygulamalar önerilmiştir. Nitekim bu öneriler, dublaj çalışmalarına özgü tekniklerle örtüşmektedir. Dublaj 3 şekilde gerçekleşebilir:

a. Orijinal versiyonunun üzerine hedef dilde konuşmalar

b. Halihazırda hedef dilde olan filmlere gölgeleme tekniği ile yapılan konuşmalar

c. Sessizleştirilmiş filmlere doğaçlama yapılan konuşmalar

Dublaj çalışmaları yüzde yüz doğruluğa sahip bir telaffuzla doğru ürünün ortaya çıkmasını amaçlar. Dahası, telaffuz hatalarının olduğu bir film/video izleyiciler tarafından düşük oranda tercih edilecektir. Ancak yabancı/ikinci dil öğrenenlerin kendi ana dillerinde yer alan karakteristik ses özellikleri, ağızdan çıkış yerlerindeki farklılıkları nedeniyle sesletimde hata yapmalarına neden olabilmektedir (Güngör, 2019). Bu nedenle özellikle yabancı/ikinci dil sınıflarında gerçekleştirilen dublaj çalışmalarını bir ürün ortaya koymaya çalışmaktan çok, dil unsurlarını en doğru biçimde kullanabilmek amacıyla aracı bir unsur olarak değerlendirmek uygun olacaktır.

Dil öğretiminde telaffuz da önemli bir husus olarak ön plana çlkmaktadır ve bu konuda sınırlı çalışma bulunmaktadır. Örneğin bu anlamda Özmen, Gürer ve Dürer (2017) telaffuz etkinlikleri olarak yüz yüze öğretim çerçevesinde gerçekleştirilecek geleneksel ve ses farkındalı̆̆ yaratacak kritik uygulamalara yer vermişlerdir. Ancak bugünün şartlarında söz konusu etkinliklerin hem yüz yüze eğitime hem de uzaktan yabancı dil öğretimine uygun hale getirilmesi gerektiğini söylemek uygun olacaktır.

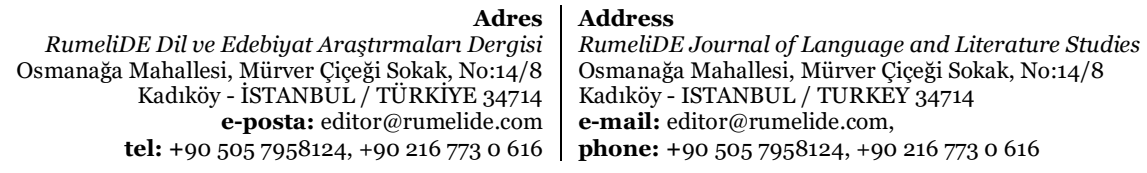




\section{Sonuç}

Dublaj bugün hızlı ve pratik (Anıl vd., 2016, s. 14) özellikleriyle ön plana çıkan ve çok yönlü; farklı uygulamaların gerçekleştirilebileceği, tekniklerinin ve boyutlarının her biriyle başta konuşma becerisi olmak üzere tüm dil becerilerine katkı sağlayacak önemli bir alandır.

Yabancı/ikinci dil öğrenenler için iyi yapılandırılmış metinlerle ve ders planlarıyla planlanacak dublaj uygulamalarının öğrencilerin özellikle telaffuz, dil kullanımının edimsel boyutları ve öğrenmede kalıcılık noktasında başarı sağlayacağı görülmekte; buradan hareketle öğrencilerin hem eğlenip hem de öğrenecekleri bir alan olarak dublaj sanatından yararlanılmasının önemini vurgulamak gerekmektedir.

Öğrenme ortamlarında ders kazanımlarına yönelik olarak gerçekleştirilecek uygulamalar, öğrencilerin dil seviyeleri göz önünde bulundurularak tasarlanmalıdır. Başlangıç seviyesi, orta seviye ve ileri seviye dil kullanıcısı olan öğrencilerle aynı tarzda dublaj uygulamaları yapmaları istendik sonuçları vermeyecektir. Ayrıca dublaj çalışmaları sonunda öğrencilerin bir işi başarmanın vermiş olduğu motivasyonla dil ve kültüre bakış açılarında olumlu duyguların açığa çıması da beklenmektedir.

\section{Kaynakça}

Akpınar, B. ve Aydın, K. (2009). Çok duyulu (multisensory) yabancı dil öğretimi. Tubav Bilim Dergisi, $2(1), 105-112$.

Al-Sharabi, T. (2020). Yabancı dil olarak Türkçe öğretiminde ezberleme yönteminin konuşma becerisine etkisi, International Journal of Teaching Turkish as a Foreign Language 3 (2), 26-39.

Al-Sobhi, B. \& Preece, A. (2018). Teaching English speaking skills to the arab students in the saudi school in Kuala Lumpur: Problems and solutions. International Journal of Education \& Literacy Studies, 6 (1), 1-11.

Anıl, A., Dedeoğlu, E. M., Baysal, E., Nergis, S. ve Görgülü, E. (2016). Türkiye'de Dublaj Sanatının Popülerleşmesi Ve Türk Dublaj Sanatçlları (Dönem Projesi). Ankara: Bilkent Üniversitesi.

Arslan, M. (2017). Yaygın (informal) eğitim bağlamında ikinci dil edinimi. Türk-İslam Dünyası Sosyal Araşttrmalar Dergisi, 4 (14), 34-47.

Aykaç, M. ve Çetinkaya, G. (2019). Konuşma Becerisi ve Yaratıcı Drama. Konuşma ve Eğitimi (Ed. G. Çetinkaya). Ankara: Pegem.

Chaume, F. (2020). Dubbing (103-132). The Palgrave Handbook of Audiovisual Translation and Media Accessibility (Eds. T. Bogucki, M. Deckert). Switzerland: Macmillan.

Council of Europe (2020), Common European Framework of Reference for Languages: Learning, teaching, assessment - Companion volume, Council of Europe Publishing, Strasbourg.

Çelik, F. (2019). Yabancılara Türkçe öğretiminde konuşma becerisi. Uluslararası Sosyal Bilimler Akademik Araştırmalar Dergisi, 3 (3), 32-41.

Dewi, R., Kultsum, U. ve Armadi, A. (2017). Using communicative games in improving students' speaking skills. English Language Teaching, 10 (1), 63-71.

Diyora, M. ve Diloz, X. (2020). Improving the English languages speaking skills with efficient ways. International Engineering Journal For Research \& Development, 5 (1), 1-7.

Eissa, H. M. S. (2019). Pedagogic effectiveness of digital storytelling in improving speaking skills of Saudi EFL learners. Arab World English Journal, 10 (1) 127-138.

Göçmen, E. (2018). Yabancı Dil Olarak Türkçe Öğretiminde Otantik Dokümanların Kullanımı ve A1-A2 Düzeyinde Dil Becerilerine Etkisi (Doktora Tezi). Hacettepe Üniversitesi Türkiyat Araştırmaları Enstitüsü, Ankara.

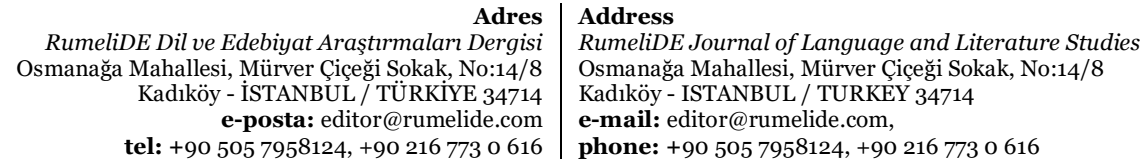


Göktürk, Ö, Çalışkan, M. ve Öztürk, M. S. (2020). Yaratıcı drama etkinliklerinin İngilizce konuşma becerisinin geliştirilmesine etkisi. Araştırma Temelli Etkinlik Dergisi, 10 (1), 1-17.

Göktürk, Ö. (2019). Yaratıcı drama etkinliklerinin İngilizce konuşma becerisine etkisi. (Yüksek Lisans Tezi). Necmettin Erbakan Üniversitesi, Eğitim Bilimleri Enstitüsü, Konya.

Göngör, H. (2019). Türkçenin Yabancı Dil Olarak Öğretiminde Akıcı Okuma: Durum Çalışması (Doktora Tezi). Bolu Abant İzzet Baysal Üniversitesi Eğitim Bilimleri Enstitüsü, Bolu.

Hamidova, S. ve Ganiyeva, H. (2020). Developing speaking skills. Архив Научных Публикаций JSPI.

Hussain, S. (2017). Teaching speaking skills in communication classroom. International Journal of Media, Journalism and Mass Communications, 3 (3), 14-21.

İnal, E. (2020). Yabancı dil öğretiminde konuşma becerisinin geliştirilmesi ve ölçme değerlendirme süreçlerine yönelik düşünceler: Öğretici yeterlikleri. Aydın Tömer Dil Dergisi, 5 (2), 189-204.

İşcan, A. \& Karagöz, B. (2016). Yabancı dil olarak Türkçe öğretiminde konuşma becerisi kazandırmada filmlerin kullanımı / The use of films to help students gain speaking abıllty in teaching Turkish as a foreign language. Atatürk Üniversitesi Sosyal Bilimler Enstitüsü Dergisi, 20 (4), 1265-1278.

İşcan, A. (2011). Yabancı dil olarak Türkçe öğretiminde filmlerin yeri ve önemi. Turkish Studies. 6 (3), 939-948.

İşisağ, U. ve Demirel, Ö. (2010). Diller için Avrupa Ortak Başvuru Metni’nin konuşma becerisinin gelişiminde kullanılması. Ĕgitim ve Bilim, 35 (156), 190-204.

Jabbarova, A. (2020). The importance of evaluating students' speaking skills. Архив Научных Публикаций JSPI, 1(77).

James, P. R. A. P., Yong, K. L., ve Yunus, M. M. (2019). Hear me out! Digital storytelling to enhance speaking skills. International Journal of Academic Research in Business and Social Sciences, 9 (2), 190-202.

Karaçam Z. (2013). Sistematik derleme metodolojisi: Sistematik derleme hazırlamak için bir rehber. Dokuz Eylül Üniversitesi Hemşirelik Fakültesi Elektronik Dergisi 6 (1): 26-33.

Kardaş, D. (2017). Türkçe öğrenen yabancıların konuşma becerisini üretimsel faaliyetler ve stratejiler açısından geliştirmede film eleştirisi tekniği. Turkish Studies, 12 (34), 261-274.

Kesici, S. (2021). Konuşma Becerisini Geliştirmek için Kullanılan Öğretim Yöntem ve Teknikleri ile İlgili Çalışmalar Üzerine Bir İnceleme (Yüksek Lisans Tezi). Pamukkale Üniversitesi Eğitim Bilimleri Enstitüsü, Denizli.

Koç, E. (2020). Yabancı dil eğitiminde görsel ve işitsel çevirinin etkileri. RumeliDE Dil ve Edebiyat Araştırmaları Dergisi, (Ö8), 758-772.

Meinawati, E., Rahmah, N. Harmoko, D. ve Dewi, N. (2020). Increasing English speaking skills through YouTube, POLYGLOT: Jurnal Ilmiah, 16 (1), 1 - 13.

Özmen, C, Güven, E ve Dürer, Z. S (2017). Yabancı dil olarak Türkçe öğretiminde konuşma becerisi: Sesletime yönelik bir uygulama ve etkinlik önerisi. Turkish Studies, 12(28), 593-634.

Perego, E. ve Pacinotti, R. (2020). Audiovisial Translation through the Ages (33-56). The Palgrave Handbook of Audiovisual Translation and Media Accessibility (Eds. T. Bogucki, M. Deckert). Switzerland: Macmillan.

Perez Gonzalez, L. (2009). Audiovisual translation (13-20). Routledge Encyclopedia of Translation Studies (Eds. M. Baker, G. Saldanha). London \& New York: Routledge.

Rao, P. S.(2019). The importance of speaking skills in English classrooms. Alford Council of International English \& Literature Journal, 2 (2), 6-18.

Sirisrimangkorn, S. (2018). The use of project-based learning focusing on drama to promote speaking skills of EFL learners. Advances in Language and Literary Studies, 9 (6), 14-20.

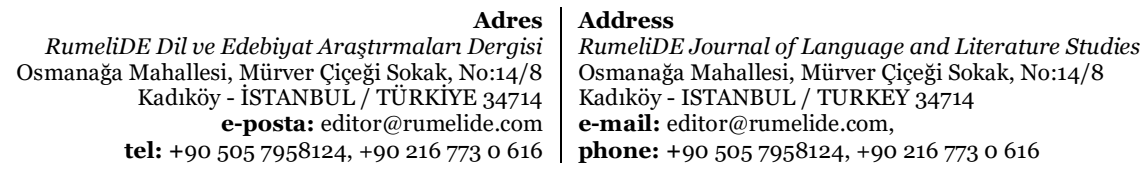


Şenyiğit, Y. \& Okur, A. (2019). Yabancllara Türkçe öğretiminde konuşma becerisi ve telaffuz eğitimi. Mehmet Akif Ersoy Üniversitesi Ĕ̈itim Fakültesi Dergisi, 52, 519-549.

Taşer, S. (2012). Konuşma Eğitimi. İstanbul: Pegasus.

Ülker, M. \& Sütçü, S. S. (2019). Dizi Filmlerle Doğal Ortamda Yabancı Dil Öğrenme: Dizi filmlerin Altyazısız İzlenmesine Kadar Geçen Sürenin Analizi (54-59). Eğitimde ve Sosyal Bilimlerde Yenilikler Sanal Sempozyumu Tam Metinler Bildiri Kitabı (Ed. S. Karataş, E. Kılıç Çakmak, Y. Doğan). Ankara: Gazi Üniversitesi.

Ülker, M. (2020). Dizi film izlemeyle dil yabancı olarak Türkçe öğrenme modeli (141-168). Eğitim Bilimlerinde Akademik Çalışmalar (Ed. D. Demirbulak, M. Yiğit). Fransa: Livre de Lyon.

Ünlüer, Arabacı, P. (2015). Yabancı dil olarak Türkçe öğretiminde yararlanılan kısa ve uzun metrajlı filmlerin Kırgızistan bağlamında değerlendirilmesi. Manas Sosyal Araştırmalar Dergisi 4 (2), 83-97.

Ünsal, F. (2019). Türkçe Derslerinde Rol Alma Modeli İle Hazırlanan Etkinliklerin Öğrencilerin Konuşma Tutum Ve Kaygılarına Etkisi (Yüksek Lisans tezi). Marmara Üniversitesi, Eğitim Bilimleri Enstitüsü, İstanbul.

Zeytinkaya, D. (2018). Filmler Yabancı Dil Öğretiminde Nasıl Etkin Bir Şekilde Kullanılabilir?. Turkophone, 5(3), 30-37.

RumeliDE Dil ve Edebiyat Araştırmaları Dergisi Osmanağa Mahallesi, Mürver Çiçeği Sokak, No:14/8 Kadıköy - İSTANBUL / TÜRKIYE 34714 e-posta: editor@rumelide.com tel: +90 $5057958124,+902167730616$
Address

RumeliDE Journal of Language and Literature Studies Osmanağa Mahallesi, Mürver Çiçeği Sokak, No:14/8

Kadıköy - ISTANBUL / TURKEY 34714

e-mail: editor@rumelide.com,

phone: +90 $5057958124,+902167730616$ 